\title{
Faktor Eskternal Dan Faktor Internāl Yang Mempengaruhi Perilaku Auditor Dalam Penghentian Prematur Prosedur Audit
}

\author{
Reni Yendrawati * \\ Wenny Hartanti Putri **
}

\begin{abstract}
This study aims to analyze whether Time Pressure, Risk Audit, Materiality, Procedures Review and Control of Quality, Supervision Measures, External Locus of Control and Self Esteem auditor effect on premature sign off audit procedures. Data collection was conducted by giving questionnaires to auditors working in KAP Yogyakarta. The method of data analysis is validity and reliability testing, hypothesis testing by means of logistic regression analysis and Friedman test.

Hypothesis testing is first performed using the Friedman test and the second to the eighth hypothesis using logistic regression. Friedman test showed that there is a priority order audit procedures that are likely to be abandoned. From the results mean rank from friedman test indicates that the use of information management assertion is a procedure that is often to be abandoned, while the physical examination is the procedure most often to be abandoned. From the logistic regression showed that time pressure, review and quality control procedures, supervision measures, external locus of control and self-esteem have a significant effect on premature sign of audit procedures. But the audit risk and materiality has no affect the premature termination of audit procedures.
\end{abstract}

Keywords : premature sign off, time pressure, audit risk, materiality, review and quality control procedures

* Dosen Fakultas Ekonomi UII

** Alumni Fakultas Ekonomi UII 


\section{Pendahuluan}

Salah satu bentuk perilaku pengurangan kualitas audit adalah penghentian premature atas prosedur audit, tindakan yang dimaksud berkaitan dengan penghentian terhadap prosedur audit yang disyaratkan, tidak melakukan pekerjaan secara lengkap dan mengabaikan prosedur audit tetapi auditor berani mengungkapkan opini atas laporan keuangan yang diauditnya.

Suryanita et al, (2006) menyimpulkan bahwa proses penghentian prematur prosedur audit disebabkan oleh faktor karakteristik personal auditor (faktor internal) dan faktor situasional saat melakukan audit (faktor internal). Dari penjabaran di atas time pressure, risiko audit, materialitas, prosedur review dan kontrol kualitas, tindakan supervisi serta external locus of control merupakan faktor eksternal yang akan diuji pengaruhnya terhadap perilaku auditor dalam penghentian prematur prosedur audit. Sedangkan faktor intemal yang akan diuji dalam penelitian ini adalah self esteem auditor.

Penelitian ini merupakan pengembangan dari penelitian Kurniawan et al, (2008) dan Ayu (2010). Penelitian Ayu (2010) menguji prosedur audit yang sering dihentikan oleh auditor dan menguji pengaruh antara time pressure, risiko audit, materialitas, prosedur review dan kontrol kualitas, serta locus of control yang memiliki dampak terhadap keputusan untuk melakukan premature sign off. Sedangkan penelitian Kurniawan et al, (2008) menguji hubungan antara time pressure, risiko audit, materialitas, prosedur review dan kontrol kualitas terhadap keputusan prermature sign off. Penelitian ini mengacu pada penelitianpenelitian di atas dengan menguji tindakan supervisi dan self esteem terhadap pengaruh dalam perilaku penghentian premature sign off. 
Penelitian ini melibatkan responden yaitu auditor yang bekerja di Daerah Istimewa Yogyakarta.

\section{Rumusan Masalah}

Berdasar latar belakang di atas, maka rumusan masalah dalam penelitian ini adalah sebagai berikut:

1. Bagaimana urutan prioritas prosedur audit yang cenderung dihentikan oleh auditor secara prematur?

2. Apakah time pressure, risiko audit, materialitas, prosedur review dan kontrol kualitas, tindakan supervisi, externallocus of control dan self esteem berpengaruh terhadap terjadinya penghentian prematur atas prosedur audit?

\section{Tujuan Penelitian}

Tujuan penelitian ini adalah sebagai berikut:

1. Untuk mengetahui prosedur audit yang sering dihentikan oleh auditor.

2. Untuk memberikan bukti empiris mengenai ada atau tidaknya pengaruh antara variabel time pressure, risiko audit, materialitas, prosedur review dan kontrol kualitas, tindakan supervisi, externallocus of control serta self esteem terhadap perilaku penghentian prematur prosedur audit.

\section{Kajian Pustaka}

\section{Pengertian Auditing}

Harjono Jusup (2001) mendefinisikan audit sebagai suatu proses sistematis untuk mendapatkan dan mengevaluasi bukti yang berhubungan untuk mendapatkan dan mengevaluasi bukti yang berhubungan dengan asersi tentang tindakan-tindakan dan kejadian-kejadian ekonomi secara 
obyektif untuk menentukan tingkat kesesuaian antara asersi tersebut dengan kriteria yang telah ditetapkan dan mengkomunikasikan hasilnya kepada pihak-pihak yang berkepentingan.

\section{Prosedur Audit}

Prosedur audit adalah instruksi rinci untuk mengumpulkan tipe bukti audit tertentu yang harus diperoleh pada saat tertentu dalam audit. Serangkaian prosedur audit yang dimaksudkan dalam penelitian ini yaitu pemahaman bisnis dan industri klien (PSA No. 5 2001), pertimbangan pengendalian internal (PSA No. 69 2001), informasi asersi manajemen (PSA No. 07 2001), review kinerja internal auditor klien (PSA No. 33 2001), prosedur analitik (PSA No. 22 2001), proses konfirmasi (PSA No. 07 2001), representasi manajemen (PSA No. 17 2001), pengujian pengendalian TABK (PSA No. 59 2001), sampling audit (PSA No. 26 2001), perhitungan fisik persediaan dank as (PSA No. 07 2001).

\section{Penghentian Prematur Prosedur Audit}

Praktik ini terjadi ketika auditor mendokumentasikan prosedur audit secara lengkap tanpa benar-benar melakukannya atau mengabaikan / tidak melakukan beberapa prosedur audit yang disyaratkan tetapi ia dapat memberikan opini atas suatu laporan keuangan.

\section{Time Pressure}

Tekanan waktu (time pressure) adalah suatu keadaan di mana auditor mendapatkan tekanan dari KAP tempatnya bekerja, untuk menyelesaikan audit pada waktu dan anggaran biaya yang telah ditentukan sebelumnya.

\section{Risiko Audit}

Risiko audit adalah risiko yang terjadi dalam hal auditor tanpa disadari tidak memodifikasi pendapat sebagaimana mestinya, atas suatu 
laporan keuangan yang mengandung salah saji material (PSA No. 5 2001).

\section{Materialitas}

FASB mendifinisikan materialitas sebagai besarnya suatu penghilangan atau salah saji informasi akuntansi yang dipandang dari keadaan-keadaan yang melingkupinya, memungkinkan pertimbangan yang dilakukan oleh orang yang mengandalkan pada informasi menjadi beruah atau dipengaruhi oleh penghilangan atau salah saji material.

\section{Prosedur Review dan Kontrol Kualitas}

Prosedur review merupakan proses memeriksa / meninjau ulang hal/pekerjaan untuk mengatasi terjadinya indikasi ketika staf auditor telah menyelesaikan tugasnya, padahal tugas yang disyaratkan tersebut gagal dilaksanakan. Sedangkan kontrol kualitas berfokus pada pelaksanaan prosedur audit sesuai dengan standar auditing.

\section{Tindakan Supervisi}

Supervisi melibatkan pengarahan usaha-usaha asisten untuk mencapai tujuan audit dan menentukan apakah tujuan telah tercapai.

\section{External Locus of Control Auditor}

Locus of Control adalah cara pandang seseorang terhadap suatu peristiwa apakah dia dapat atau tidak dapat mengendalikan peristiwa yang terjadi..Locus of control dibedakan menjadi internal locus of control dan external locus of control.

\section{Self Esteem}

Self esteem adalah suatu keyakinan nilai diri sendiri berdasarkan evaluasi diri secara keseluruhan. 


\section{Penelitian Terdahulu}

Penelitian Herningsih (2001) menyimpulkan bahwa prosedur audit yang sering ditinggalkan auditor adalah mengurangi jumlah sampel yang telah direncanakan dalam audit laporan keuangan. Dalam penelitian ini dapat diketahui adanya pengaruh signifikan antara time pressure dan risiko audit terhadap penghentian premature prosedur audit. Namun penelitian ini tidak dapat membuktikan tingkat materialitas berpengaruh terhadap premature sign off.

Penelitian Ayu (2010) membuktikan bahwa pemahaman terhadap bisnis klien merupakan prosedur audit yang sering dihentikan dan proses konfirmasi merupakan prosedur yang jarang dihentikan. Hasil dari penelitian Ayu adalah terdapat pengaruh positif antara time pressure, risiko audit, dan locus of control terhadap premature sign off. Sedangkan materialitas serta prosedur review dan kontrol kualitas memiliki pengaruh negatif terhadap premature sign off.

Penelitian Kurniawan et al, (2008) membuktikan bahwa terdapat pengaruh signifikan antara time pressure, risiko audit, materialitas serta prosedur review dan kontrol kualitas terhadap penghentian prematur prosedur audit.

\section{Hipotesis Penelitian}

Hipotesis dalam penelitian ini adalah sebagai beikut:

1. $\mathrm{Ha}_{1}$ : Terdapat urutan prioritas dari prosedur audit yang dihentikan

2. $\mathrm{Ha}_{2}$ : Time pressure berpengaruh positif terhadap penghentian prematur atas prosedur audit

3. $\mathrm{Ha}_{3}$ : Risiko audit berpenganh negatif terhadap penghentian prematur atas prosedur audit 
4. $\mathrm{Ha}_{4}$ : Materialitas berpengaruh negatif terhadap penghentian prematur atas prosedur audit

5. Ha : Prosedur review dan kontrol kualitas yang dilakukan KAP berpengaruh negatif terhadap penghentian prematur atas prosedur audit

6. $\mathrm{Ha}_{6}$ : Intensitas tindakan supervisi berpengaruh negatif terhadap kecenderungan melakukan penghentian prematur atas prosedur audit

7. $\mathrm{Ha}_{7}$ : External Locus of Control berpengaruh positif terhadap penerimaan perilaku disfungsional audit (dalam penghentian prematur atas prosedur audit)

8. $\mathrm{Ha}_{8}$ : Self esteem berpengaruh negatif terhadap penghentian prematur atas prosedur audit

\section{Metode Penelitian}

\section{Populasi dan Sampel}

Populasi penelitian ini adalah seluruh auditor independen yang bekerja pada KAP. Sampel dari penelitian ini adalah auditor yang bekerja di KAP Yogyakarta. Teknik pengambilan sampel menggunakan metode convenience sampling, dengan alasan kemudahan waktu dan biaya.

\section{Statistik Deskriptif}

Digunakan untuk memberikan gambaran mengenai demografi responden penelitian.

\section{Metode Analisis Data}

Sebelum dilakukan pengujian hipotesis, terlebih dahulu dilakukan uji validitas dan reliabilitas. Pengujian hipotesis sebagai berikut: 


\section{Uji Friedman}

Hipotesis 1 diuji dengan uji Friedman, yang digunakan untuk menentukan peringkat prioritas penghentian prematur prosedur audit.

\section{Analisis Regresi Logistik}

Hipotesis 2 sampai 8 diuji menggunakan analisis regresi logistik. Model regresi logistik yang digunakan dalam penelitian ini dirumuskan sebagai berikut :

$$
Y=\alpha+b_{1} x_{1}+b_{2} x_{2}+b_{3} x_{3}+b_{4} x_{4}+b_{5} x_{5}+b_{6} x_{6}+b_{7} x_{7}+e
$$

$\mathrm{Y}$ : Penghentian prematur prosedur audit

1 : Jika pernah melakukan penghentian prematur

0 : Jika tidak pernah melakukan penghentian premature

$\alpha$ : Konstanta, $b_{1-7}:$ Koefisien regresi, $x_{1}:$ Time Pressure, $x_{2}:$ Risiko Audit, $\mathrm{x}_{3}$ : Materialitas, $\mathrm{x}_{4}$ : Prosedur Review dan Kontrol Kualitas, $\mathrm{x}_{5}$ :Tindakan Supervisi, $\mathrm{x}_{6}$ : Locus of Control, $\mathrm{x}_{7}$ : Self Esteem, e: Error

\section{Hasil Analisis Dan Pembahasan}

Peneliti telah menyebarkan 45 kuesioner dengan jumlah 41 yang kembali dan dapat diolah. Untuk mengetahui karakteristik dari sampel, berikut ini akan disajikan statistik deskriptis dari responden.

\section{Analisis Deskriptif}

Tabel 1: Berdasarkan Tkt. Pend

\begin{tabular}{|l|c|c|c|}
\hline No. & Pendidikan & Jumlah & Presentase \\
\hline $\mathbf{1}$ & S2 & 5 & $12.2 \%$ \\
\hline $\mathbf{2}$ & S1 & 34 & $82.9 \%$ \\
\hline $\mathbf{3}$ & D3 & 1 & $2.4 \%$ \\
\hline $\mathbf{4}$ & Lainnya & 1 & $2.4 \%$ \\
\hline & Total & 41 & $100 \%$ \\
\hline
\end{tabular}


Tabel 2: Berdasarkan Jenis Kelamin

\begin{tabular}{|c|c|c|c|}
\hline No. & Jenis Kelamin & Jumlah & Presentase \\
\hline 1. & Laki - laki & 27 & $65.9 \%$ \\
\hline 2. & Perempuan & 14 & $34.1 \%$ \\
\hline & Total & 41 & $100 \%$ \\
\hline
\end{tabular}

Tabel 3 Berdasarkan Jabatan

\begin{tabular}{|c|c|c|c|}
\hline No. & Posisi & Jumlah & Presentase \\
\hline 1. & Junior Auditor & 25 & $61.0 \%$ \\
\hline 2. & Senior Auditor & 14 & $34.1 \%$ \\
\hline 3. & Manager & 2 & $4.9 \%$ \\
\hline & Total & 41 & $100 \%$ \\
\hline
\end{tabular}

Tabel 4 Berdasarkan Lama Kerja

\begin{tabular}{|c|c|c|c|}
\hline No. & Lama Bekerja & Jumlah & Presentase \\
\hline 1. & $<2$ tahun & 24 & $58.5 \%$ \\
\hline 2. & $2-5$ tahun & 7 & $17.1 \%$ \\
\hline 3 & $>5$ tahun & 10 & $24.4 \%$ \\
\hline & Total & 41 & $100 \%$ \\
\hline
\end{tabular}

\section{Uji Validitas dan Uji Reliabilitas}

Setelah dilakukan uji validitas dan reliabilitas didapatkan hasil bahwa kuesioner dinyatakan valid dan reliabel.

\section{Pengujian Hipotesis 1 (Uji Friedman)}

Tabel 6 : Uji Friedman

\begin{tabular}{|l|c|l|l|}
\hline \multicolumn{1}{|c|}{ Prosedur Audit } & $\begin{array}{l}\text { Mean } \\
\text { Rank }\end{array}$ & $\begin{array}{l}\text { Chi } \\
\text { Square }\end{array}$ & p-value \\
\hline Pemahaman bisnis internal klien & 5.220 & 20.862 & 0.013 \\
\hline Pertimbangan pengendalian internal & 5.707 & & \\
\hline Informasi asersi manajemen & 4.244 & & \\
\hline Pertimbangan internal auditor & 4.793 & & \\
\hline Prosedur analitis & 6.268 & & \\
\hline Konfirmasi & 6.037 & & \\
\hline Representasi manajemen & 5.134 & & \\
\hline Pengujian TABK & 5.183 & & \\
\hline Mengurangi sampel & 5.878 & $\cdot$ & \\
\hline Pemeriksaan fisik & 6.537 & & \\
\hline
\end{tabular}


Tabel 6 menunjukkan nilai Assypm. Sig sebesar 0.013 yang dapat diartikan bahwa $\mathrm{H}_{0}$ ditolak / Ha pertama diterima atau dapat dinyatakan bahwa terdapat urutan prioritas dari prosedur audit yang dihentikan. Untuk mengetahui urutan prioritas prosedur audit yang cenderung ditinggalkan dapat dilihat dari Mean Rank. Tabel di atas menunjukkan bahwa menggunakan asersi manajemen merupakan prosedur yang paling sering ditinggalkan. Dan pemeriksaan fisik merupakan prosedur yang paling jarang ditinggalkan.

\section{Pengujian Hipotesis 2-8 (Regresi Logistik)}

Tabel 7:Hasil Regresi Logistik

\begin{tabular}{|l|c|c|c|c|}
\hline \multicolumn{1}{|c|}{ Variabel } & Koef Regresi & Wald & Sig. & Ket \\
\hline Konstanta & 20.903 & 1.904 & 0.168 & . \\
\hline Time pressure & 10.159 & 5.288 & 0.021 & $\mathrm{Ha}_{2}$ didukung \\
\hline Risiko audit & -0.964 & 0.937 & 0.333 & $\begin{array}{c}\text { Ha } \\
\text { didukung }\end{array}$ \\
\hline Materialitas & 5.959 & 2.303 & 0.129 & $\begin{array}{c}\text { Ha } \\
\text { didukung }\end{array}$ \\
\hline Prosedur review & -7.697 & 4.135 & 0.042 & Ha $_{5}$ didukung \\
\hline $\begin{array}{l}\text { Tindakan } \\
\text { supervisi }\end{array}$ & -15.628 & 5.289 & 0.021 & $\mathrm{Ha}_{6}$ didukung \\
\hline Locus of control & 9.992 & 4.109 & 0.043 & $\mathrm{Ha}_{7}$ didukung \\
\hline Self esteem & -7.602 & 3.872 & 0.049 & $\mathrm{Ha}_{8}$ didukung \\
\hline
\end{tabular}

Berdasarkan tabel diatas dapat disusun persamaan sebagai berikut :

$$
\begin{aligned}
\text { PSO }= & 20.903+10.159 \mathrm{TP}-0.964 \mathrm{RA}+5.959 \mathrm{M}-7.697 \mathrm{PR}- \\
& 15.628 \mathrm{TS}+9.992 \mathrm{LOC}-7.206 \mathrm{SE}
\end{aligned}
$$

\section{Pembahasan}

\section{Time Pressure}

Hasil perhitungan pada regresi diperoleh nilai Wald hitung sebesar 5,288 dan p-value sebesar 0,021 yang nilainya dibawah 0,05 . Dengan demikian $\mathrm{Ho}_{2}$ ditolak dan $\mathrm{Ha}_{2}$ diterima yang berarti bahwa Time Pressure 
berpengaruh signifikan positif terhadap penghentian prematur prosedur audit pada KAP di Yogyakarta. Dengan demikian hipotesis kedua yang menyatakan bahwa Time pressure berpengaruh positif terhadap penghentian prematur atas prosedur audit, dapat didukung.

Hasil penelitian ini sesuai dengan penelitian yang dilakukan oleh Herniningsih (2001) yang menyimpulkan bahwa ada hubungan yang signifikan antara time pressure terhadap penghentian prematur prosedur audit.

Hasil analisis regresi logistik menunjukkan bahwa ada pengaruh positif dan signifikan antara tekanan waktu terhadap penghentian prematur atas prosedur audit. Hal ini dapat diartikan, jika tekanan waktu semakin meningkat maka penghentian prematur atas prosedur audit juga semakin meningkat.

Auditor menetapkan alokasi waktu audit yang sangat ketat, tetapi akibatnya memiliki efek samping yang merugikan publik, yaitu memunculkan perilaku yang mengancam kualitas audit, antara lain penurunan tingkat pendeteksian dan penyelidikan aspek kualitatif salah saji, gagal meneliti prinsip akuntansi, melakukan review dokumen secara dangkal, menerima penjelasan klien secara lemah dan mengurangi pekerjaan pada salah satu langkah audit di bawah tingkat yang diterima.

Di bawah tekanan-tekanan waktu, pethatian akan lebih terfokus pada tugas yang dominan seperti tugas pengumpulan bukti berkaitan dengan frekuensi dan jumlah salah saji dan mengorbankan perhatian yang diberikan pada tugas tambahan seperti tugas yang memberikan aspek kualitatif atas terjadinya salah saji yang menunjukkan potensial kecurangan pelaporan keuangan.

Alokasi waktu penugasan waktu audit biasanya ditentukan diawal penugasan.Auditor bisa menerima penugasan audit beberapa kali. Dalam 
hal ini pimpinan Kantor Akuntan Publik menetapkan alokasi waktu audit yang sama untuk penugasan pertama maupun penugasan kedua. Saat melakukan audit pertama kali, auditor dapat dikatakan mengalami batasan waktu audit, karena auditor harus mempelajari terlebih dahulu karakteristik perusahaan klien, bagaimana sistem pengendaliannya,, bagaimana kondisí bisnis dan industri klien, dll. Sedangkan saat melakukan penugasan audit untuk yang kedua, dan seterusnya, auditor tidak perlu lagi mempelajari karakteristik perusahaan klien, karena auditor telah mempelajari perusahaan klien saat dia melakukan penugasan pertama kali. Auditor dituntut untuk dapat menyelesaikan prosedur audit yang disyaratkan dalam waktu yang sesingkat-singkatnya sesuai dengan batasan waktu penugasan dan menghasilkan laporan tepat pada waktunya.

\section{Risiko Audit}

- Hasil perhitungan pada regresi diperoleh nilai Wald hitung sebesar $=-0,937$ dan $\mathrm{p}$-value sebesar 0,333 yang nilainya diatas 0,05 . Dengan demikian $\mathrm{Ho}_{3}$ diterima dan $\mathrm{Ha}_{3}$ ditolak yang berarti bahwa Risiko Audit tidak berpengaruh signifikan terhadap penghentian prematur prosedur audit pada KAP di Yogyakarta. Dengan demikian hipotesis ketiga yang menyatakan bahwa Risiko Audit berpengaruh positif terhadap penghentian prematur atas prosedur audit, tidakdapat didukung.

Risiko audit tidak berpengaruh signifikan terhadap penghentian prematur atas prosedur audit, yang mungkin disebabkan karena berdasarkan persepsi responden (analisis deskriptif) menunjukkan bahwa responden memberikan penilaian yang tinggi pada risiko audit. Ketika risiko audit yang dihadapi oleh audit tinggi berarti auditor perlu mengumpulkan bahan bukti audit yang luas, artinya memerlukan prosedur audit yang banyak. Penetapan risiko yang besar ini kemungkinan dikarenakan auditor belum ${ }^{-}$merasa yakin bahwa tanpa melakukan 
prosedur audit tertentu, opini audit yang dibuat tidak akan salah sehingga akuntan akan melakukan prosedur audit sesuai ketentuan, dan memprioritaskan prosedur audit dalam menjalankan proses auditor, oleh karena itu resiko audit tidak akan mempengaruhi penghentian prematur atas prosedur audit, sehingga tindakan penghentian atas prosedur audit kemungkinan tidak terjadi.

\section{Variabel Materialitas}

Hasil perhitungan pada regresi diperoleh nilai Wald hitung sebesar 2,303 dan $\mathrm{p}$-value sebesar 0,129 yang nilainya diatas 0,05.Dengan demikian $\mathrm{Ho}_{4}$ diterima dan $\mathrm{Ha}_{4}$ ditolak yang berarti bahwa Materialisme tidak berpengaruh signifikan terhadap penghentian prematur prosedur audit pada KAP di Yogyakarta. Dengan demikian hipotesis keempat yang menyatakan bahwa Materialisme berpengaruh negatif terhadap penghentian prematur atas prosedur audit, tidak dapat didukung.

Hasil penelitian ini sesuai dengan penelitian yang dilakukan oleh Herniningsih (2001) yang menyimpulkan bahwa tidak ada hubungan yang signifikan antara materialisme terhadap penghentian prematur prosedur audit.

Tidak signifikannya variabel Materialitas terhadap proses penghentian prematur atas prosedur audit hal ini mungkin disebabkan karena sebagian besar akuntan ini masih memiliki pengalaman yang cukup rendah, yang ditunjukkan dengan masa kerja yang sebagian besar kurang dari 2 tahun, sehingga dalam memahami materialitas seperti pengurangan jumlah sampel audit, pemeriksaan fisik terhadap kas / persediaan atau konfirmasi dengan pihak ketiga, sehingga menimbulkan ketidakcermatan bagi auditor. Sebagai contoh dalam menyatakan opini kewajaran suatu laporan keuangan, auditor harus mengumpulkan bukti-bukti audit dari prosedur yang disyaratkan dengan mempertimbangkan tingkat materialitasnya. 
Auditor yang kurang berdedikasi tinggi akan kurang menghasilkan laporan audit yang baik karena keterbatasan pada pengalaman, pengetahuan dan kecakapan yang dimiliki.

\section{Prosedur Review dan Kontrol Kualitas}

Hasil perhitungan pada regresi diperoleh nilai Wald hitung sebesar 4,135 dan $p$-value sebesar 0,042 yang nilainya dibawah 0,05.Dengan demikian $\mathrm{Ho}_{5}$ ditolak dan $\mathrm{Ha}_{5}$ diterima yang berarti bahwa prosedur review dan kontrol kualitas berpengaruh signifikan terhadap penghentian prematur prosedur audit pada KAP di Yogyakarta. Dengan demikian hipotesis kelima yang menyatakan bahwa prosedur review dan kontrol kualitas yang dilakukan Kantor Akuntan Publik berpengaruh negatif terhadap penghentian prematur atas prosedur audit, dapat didukung.

Hasil penelitian ini sesuai dengan penelitian yang dilakukan oleh Suryanita et al, (2006) yang menyimpulkan bahwa ada hubungan negatif yang signifikan antara prosedur review dan kontrol kualitas terhadap penghentian prematur prosedur audit.

Hal ini disebabkan karena pelaksanaan prosedur review dan kontrol kualitas yang baik akan meningkatkan kemungkinan terdeteksinya perilaku auditor yang menyimpang, seperti praktik penghentian prematur atas prosedur audit. Kemudahan pendeteksian ini akan membuat auditor berpikir dua kali ketika akan melakukan tindakan semacam penghentian prematur atas prosedur audit.

\section{Tindakan Supervisi}

Hasil perhitungan pada regresi diperoleh nilai Wald hitung sebesar 4,289 dan p-value sebesar 0,021 yang nilainya dibawah 0,05.Dengan demikian $\mathrm{Ho}_{6}$ ditolak dan $\mathrm{Ha}_{6}$ diterima yang berarti bahwa tindakan supervisi berpengaruh signifikan terhadap penghentian prematur prosedur audit pada KAP di Yogyakarta. Dengan demikian hipotesis keenam yang 
menyatakan bahwa tindakan supervisi yang dilakukan Kantor Akuntan Publik berpengaruh negatif terhadap penghentian prematur atas prosedur audit, dapat didukung.

- Hal ini disebabkan karena supervisi mencakup pengarahan kegiatan pemeriksa dan pihak lain (seperti tenaga ahli yang terlibat dalam pemeriksaan) agar tujuan pemeriksaan dapat dicapai. Tujuan audit dapat tercapai jika tidak terjadi penghentian prematur atas prosedur audit.Tindakan-tindakan yang dilakukan dalam supervisi diharapkan dapat mencegah penghentian prematur atas prosedur audit.

Selain itu, pelaksanaan supervisi yang kurang baik juga merupakan salah satu faktor yang mengakibatkan terjadinya penghentian prematur dalam audit. Kantor Akuntan Publik (KAP) yang pelaksanaan supervisinya kurang baik, tidak melakukan prosedur review makalah Audit, sehingga kegagalan auditor dalam melaksanakan seluruh tugas yang ditetapkan tidak dapat terdeteksi.

\section{External Locus of controlAuditor}

Hasil perhitungan pada regresi diperoleh nilai Wald hitung sebesar 4,109 dan $p$-value sebesar 0,043 yang nilainya dibawah 0,05 .Dengan demikian $\mathrm{Ho}_{7}$ ditolak dan $\mathrm{Ha}_{7}$ diterima yang berarti bahwa externallocus of control berpengaruh signifikan terhadap penghentian prematur prosedur audit pada KAP di Yogyakarta. Dengan demikian hipotesis ketujuh yang menyatakan bahwa externallocus of controlauditor berpengaruh positif terhadap penghentian prematur atas prosedur audit, dapat didukung.

Individu yang memiliki internal locus of control cenderung menghubungkan hasil atau outcome dengan usaha-usaha mereka atau mereka percaya bahwa kejadian-kejadian, adalah di bawah pengendalian 
atau kontrol mereka dan mereka memiliki komitmen terhadap tujuan organisasi yang lebih besar dibandingkan individu yang memiliki externallocus of control.Di samping itu individu yang memiliki externallocus of control adalah individu yang percaya bahwa mereka tidak dapat mengontrol kejadian-kejadian dan hasil atau outcome (Spector, 1982 dalam Donelly et al, 2003).

Dalam konteks auditing tindakan manipulasi atau penipuan akan terwujud dalam bentuk perilaku disfungsional. Perilaku ini memiliki arti bahwa auditor akan memanipulasi proses auditing untuk mencapai tujuan kinerja individu. Pengurangan kualitas auditing bisa dihasilkan sebagai pengorbanan yang harus dilakukan auditor untuk bertahan di lingkungan audit.

\section{Self EsteemAuditor}

Hasil perhitungan pada regresi diperoleh nilai Wald hitung sebesar 3,872 dan $p$-value sebesar 0,049 yang nilainya dibawah 0,05 . Dengan demikian $\mathrm{Ho}_{8}$ ditolak dan $\mathrm{Ha}_{8}$ diterima yang berarti bahwa self esteemauditorberpengaruh signifikan terhadap penghentian prematur prosedur audit pada KAP di Yogyakarta. Dengan demikian hipotesis kedelapan yang menyatakan bahwa self esteemauditor berpengaruh negatif terhadap penghentian prematur atas prosedur audit, dapat didukung.Orang-orang yang mempunyai self esteem tinggi adalah orangorang yang memiliki komitmen atau prinsip hidup yang lebih baik dalam melakukan segala hal untuk mencapai tujuannya. Seseorang yang memiliki self esteem tinggi dapat mengatasi kegagalan dengan lebih baik daripada orang-orang yang memiliki self esteem rendah. Jika dihubungkan dengan profesi auditor, maka semakin tinggi komitmen yang dipegang oleh auditor, berarti auditor tersebut melaksanakan prosedur audit sesuai dengan ketentuan yang telah ditetapkan tanpa 
mengabaikan salah satu prosedur, sehingga tindakan penghentian atas prosedur audit semakin kecil

\section{Penutup}

\section{Kesimpulan}

Berdasar hasil analisis, maka kesimpulan dalam penelitian ini adalah sebgai berikut:

a. Hasil Uji Friedman menunjukkan terdapat urutan prioritas dari prosedur audit yang dihentikan, menggunakan informasi asersi merupakan prosedur yang paling sering ditinggalkan dan pemeriksaan fisik merupakan prosedur yang paling jarang ditinggalkan.

b. Hasil analisis regresi logistik menunjukkan bahwa ada pengaruh signifikan positif antara time pressure dan externallocus of control terhadap penghentian prematur atas prosedur audit. Terdapat pengaruh signifikan negatif antara prosedur review dan kontrol kualitas, tindakan supervisi dan self esteem terhadap penghentian prematur atas prosedur audit. Dan juga menunjukkan bahwa tidak ada pengaruh signifikan antara risiko audit dan materialitas terhadap penghentian prematur atas prosedur audit.

\section{Saran}

Penelitian ini memberi saran sebagai berikut:

a. Diharapkan penelitian selanjutnya dapat menggunakan responden yang bervariatif dan menggunakan sampel yang lebih banyak

b. Penelitian selanjutnya diharapkan dapat menambah metode wawancara dalam pengumpulan data .

c. Penelitian selanjutnya dapat dilakukan dengan menggunakan

- variabel lain yang dapat mempengaruhi terjadinya penghentian 
prematur prosedur audit (need for approval, need for achievement serta competitive type behaviour).

\section{DAFTAR PUSTAKA}

Dewi, Maya Setya, Pengaruh Pelatihan dan Tindakan Supervisi pada Keputusan Premature Sign-Off,Tesis Magister Akuntansi, Program Pascasarjana UGM, Yogyakarta, 2008.

Ghozali, Imam,Aplikasi Analisis Multivariate dengan Program SPSS, Edisi Ketiga, Badan Penerbit Universitas Diponegoro, Semarang, 2005.

Hargasari, Pipin, Pengaruh Faktor Eksternal dan Internal terhadap Penghentian Prematur atas Prosedur Audit yang Dilakukan oleh Auditor, Skripsi S1 UII, Yogyakarta, 2007.

Herningsih, Sucahyo, Penghentian Prematur atas Prosedur Audit : Studi Empiris pada Kantor Akuntan Publik,Tesis Magister Akuntansi, Universitas Gajah Mada. Yogyakarta, 2001.

IAI Kompartemen Akuntan Publik, Standar Profesional Akuntan Publik,Jakarta : Salemba Empat, 2001.

Indarto, Stefani Lily dkk., Analisis Faktor-Faktor yang Mempengaruhi Penghentian Prematur atas Prosedur Audit,Dinamika Sosial Ekonomi Vol. 7 No. 2, 2011.

Jusup, A.H., Auditing (Pengauditan), STIE YKPN, Yogyakarta, 2001. Lestari, Ayu Puji, Faktor-Faktor yang Mempengaruhi Perilaku Auditor Dalam Penghentian Prematur Prosedur Audit, Skripsi S1 UNDIP, Semarang, 2010.

Maulina, Mutia dkk.,Pengaruh Tekanan Waktu Dan Tindakan Supervisi terhadap Penghentian Prematur Prosedur Audit, Simposium Nasional Akuntansi 13, Purwokerto, 2010.

Mulyadi, Auditing 1 : Edisi Enam, Salemba Empat, Jakarta, 2002. Sugiyono, DR, Statistik untuk Penelitian,Bandung : Alfabeta, 2010.

Wahana Komputer, SPSS 17 untuk Pengolahan Data Statistik, ANDI OFFSET, Yogyakarta, 2009.

Wahyudi, Imam dkk.,Praktik Penghentian Prematur atas Prosedur Audit. Media Riset Akuntansi Vol.1 No. 2, 2011.

Weningtyas, Suryanita dkk., Penghentian Prematur atas Prosedur Audit. Simposium Nasional Akuntansi 9, Padang, 2006.

Wibowo, Kurniawan Puji dkk.,Profesionalisme Auditor dalam Penghentian Prematur atas Prosedur Audit, Semarang, 2008. 
Widarjono, Agus, Analisis Statistika Multivariat Terapan, Yogyakarta : UPP STIM YKPN, 2010

Yamin, Sofyan, Lien A. Rachmach, Heri Kurniawan, Regresi dan Korelasi dalam Genggaman Anda, Salemba Empat, Jakarta, 2011.

Yuliana, Amalia dkk.,Pengaruh Time Pressure dan Resiko Audit Terhadap Penghentian Prematur atas Prosedur Audit,Jurnal Cakrawala Akuntansi Vol. 1 No. I Hal. 21-32, 2009 
